\title{
The Effect Of Service-Driven Market Orientation On Service Innovation: Literature Review And New Research Framework
}

\author{
Seng Ratny, Xi'an Jiaotong University, P.R. China \\ Arif Mohammad Arshad, Xi'an Jiaotong University, P.R. China \\ Tian Gaoliang, Xi'an Jiaotong University, P.R. China
}

\begin{abstract}
The aim of this paper is to analyse the literature regarding the association between service-driven market orientation and innovation in service organizations as well as create conceptual framework about this relationship. Scholars have suggested that the service firms implementing service-driven market orientation can perform significantly better than traditional market-orientation and become increasingly aware of market demands better than their competitors. The service firms need to react quickly and effectively to changing customers' demands. Bring in the service-driven market orientation model for service sector leads to critical advantages and particularly their benefits on service innovation. The recent work examined the market orientation-innovation relationship regarding the service industries. An examination regarding the market orientation in service organization is presented along with the conceptual framework and conceptual model is recommended.
\end{abstract}

Keywords: Service-Driven Market Orientation; Service Innovation; Learning Orientation; Customer Orientation; Competitor Orientation

\section{INTRODUCTION}

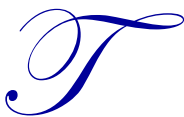

he importance of service sector is evident almost by any economic measurement formed by all precautions, services rule over the most of developed economies. The proportion of service sector is fairly much more than $50 \%$ of countries GDP and the projected job surge in the twenty-first century are forecasted to be ruled over by service sector (Pilat, 2000). In addition, growth, globalization of services and high-speed technological rise in the sector of information and communication technology are elevating the challenges for service firms to keep competitive on new promotions (Menor, Tatikonda \& Sampson, 2002). The positive results that occur from delivering new services includes: (1) raising the profits of current programs, (2) inviting new clients to the firm, (3) raising the trustworthiness of already present customers, and (4) unleashing new potential markets (Storey \& Easingwood, 1999).

In today's business environment the foundation of competitive advantage has changed from quality to innovation. Innovation enables firm's adaption to changes swiftly and assists for discovering innovative products, markets, owing to this, safeguard themselves from volatile environment. Numerous firms that have taken advantage of innovation raised their earnings and market share (Zehir, Ertosum, Zehir \& Muceldilli, 2012). Since, it is now largely valued in tumultuous market economies, innovation is definitely elixir of life for organizations irrespective of their size or other features. Growth, achievement and endurance, all rely on the capability of firms' to innovate on a constant basis. Simultaneously, knowledge is recognized as being the foremost element for the concoction of innovation. The necessity of each and every innovation is either the creation of brand new knowledge or, otherwise, and much more generally, the blend of already present bits of knowledge in unique, "entrepreneurial" ways (Drucker, 1985; Varis \& Littunen, 2010). 
In an amazingly short period of time, economic globalization has altered world's economic order, facing new challenges and business opportunities. Customers are evolving into more refined, segmented and challenging, and can anticipate regarding customization, new newness, price and quality. To accommodate these customer's wants and needs, organizations ought to deliver high quality standardized products that are innovative and environmentally friendly. In this regard, the management of innovation, customer satisfaction and the rendering of quality and environmental principles in firms are deemed to be necessary for organizations to strive in the markets.

The primary goal of a market-oriented organization is to satisfy customers (e.g. Levitt, 1960). Observing closely customers is believed to be critical for majority of successful organizations (Peters \& Waterman, 1982). Customeremployee contact like salesmen need to stress on sales coupled with customer orientation (Saxe \& Weitz, 1982). A market-oriented firm synchronizes its actions around the goal of meeting customer's unmet needs and wants (Boyd \& Walker, 1990). Service firms should possess marketing skills that are necessary for service firms and marketing orientation should be based on customers' satisfaction (Parasuraman, Berry \& Zeithaml, 1983). The relationship between market orientation and innovation in recent years has gained popularity. But, most of the research work about the connection between market orientation and firm performance is mainly product oriented with few exceptions (Matear, Osbome, Garrett \& Gray, 2002). Furthermore, current market orientation is specified and created primarily from the management or the employee perspective. In fact, this strategic construct needs to be meticulously created from the customer's perspective. The customer's feedback should not be ignored because they are the users of the services rendered (Voon, 2006). Business organizations, particularly service organizations, create value for customers by means of distinctive market related activities or performances. Nevertheless, these services patterns and pursuits needs to be market oriented. The marketing philosophy as well as the modern market orientation theories are essential in improving service quality and could be integrated in order to building a market orientated framework which is pro-service. This is due to the fact the current market orientation conceptualizations and measurements are comparatively less service-oriented in nature (Voon, 2006). Therefore, authors suggest that further studies are required to boost the validity and reliability of relationship between service-driven market orientations with service innovation.

Also, there is very little empirical investigation carried out about the relationship between Service-driven market orientation and service innovation in the service industry. The objective of this study is to add to the literature on service innovation by developing a research framework that aims to describe service innovation. This research presents the relationship between service-driven market orientation and service innovation and to investigate whether practicing service-driven market orientation can bring about superior service innovation. This research also evaluates the influence of service-driven market-orientation on service innovation mediated by the learning orientation. Also, paper presents the framework associating service driven market orientation, learning orientation and service innovation.

\section{Service Innovation}

Innovation is defined as "the act of introducing something new" (American Heritage Dictionary of the English Language, 2000). The motivation behind service innovations are largely customers' demand for the new services and management wish to unveiling new services for the present markets or identify brand new market niches for available services (Matthews \& Shulman, 2005; Osborne, 1998). Service innovation can be termed as new additions in pursuit to offer key service products for numerous factors in order to enhance primary service products to make them more fascinating to clients. Such innovations are more likely to incorporate relationships with customers and often linked with either existing or new service packs (Oke, 2007). Johne and Storey (1998) of the view that service suppliers must develop genuine sort of service product and develop the suitable nature of communication with customers since the communication process is usually a crucial aspect of an offering. Service innovations are, therefore associated with various forms in product offering or add-on services, enhancing the service experience for the customers.

The goal of innovation is to pinpoint new prospects so as to manufacture new products, services or work routines (Axtell, Holman, Unsworth, Wall, Waterson \& Harrington, 2000). The aim of employing unique service innovation practices is to design new opportunities by producing new business models, analysing employee performance, organizing customer experience and dispensing process innovation (Berry, Shankar, Parish, Cadwallader \& Dotzel, 
2006). The innovative business processes play most significant function in the global success for companies. It is the attribute that offers the company edge against their competitors through special benefit of innovation. Due to technological innovations service organizations are expanding extremely fast because the levels of competition between them is gaining momentum every day. Therefore, these firms are carrying out their work very diligently to deliver high quality services to their customers far better than their competing firms (Rönnbäck \& Witell, 2008).

The anticipation of customers ensures critical role in the service development process. Service firms need to come up with better connection with customers to fulfil services demand through the participation of customers in their service delivery process coupled with long term loyalty. Therefore, customer orientation acts more vital factor in service firms than in delivery of tangible product firms. Also, during service innovation process, customers opinions and response for innovation pursuits and programs is more invaluable than in tangible products (Alam \& Perry, 2002).

Generally, the kinds of innovations are categorized as technical and administrative. Technical innovations involve development of new services or products (Damanpour, 1991). The technical innovations consist of both product and process innovation. Product innovation is related with the growth and creation of novel or superior products and services. Process innovation entails the usage of new or enhanced techniques for delivery or production of service. The administrative innovations related to new policies, methods, and organizational procedures (Jiménez-Jimenez, Valle \& Hernandez-Espallardo, 2008).

\section{Learning Orientation}

Learning orientation describes organisation-wide endeavours of initiating and employing knowledge about customer demands, market shifts, and rival activities to reinforce competitive edge (Calantone, Cavusgil \& Zhao, 2002). In order to preserve competitive advantage in the today's competitive market environments organizations should setup, continue to keep and acquire assets as well as ought to evaluate regularly the performance of their resources and market know-how. According to these studies organizations should consistently try to learn new concepts, capabilities and techniques for the sake of conform to the market environment transition and thus organizations should embrace learning orientation (Kim \& Atuahene-Gima, 2010; Fang, Chang, Ou \& Chou, 2014). Learning orientation signifies a range of organizational beliefs that typically relate to the frame of the mind of the firm to learning, shared vision, and open-mindedness (Sinkula, Baker \& Noordewier, 1997). It is a concept that stresses on higher order learning, or gernative learning in generating highly effective ideas and actions for creating competitive advantage (Fang et al. 2014; Baker \& Sinkula, 1999; Slater \& Narver, 1995). It exhibits itself in a behavioural norm that influences the development and processing of market information and thus unlike market orientation concept that just brings out adaptive learning (Celuch, Kasouf \& Pemvemb, 2002). The learning processes are hard to formulate, unique, intangible and profoundly embedded into the roots of the organization. Therefore, firms learning ability is tough to replicate or purchase and can work as a long lasting way to get outstanding performance (Hult, Ketchen \& Slater, 2002). Learning orientation organizations are ready to challenge their sophisticated systems and renovate working beliefs (Slater \& Narver, 1995). They also predict market and environmental variations to make corrections (Calantone et al. 2002). Learning therefore encourages the behavioural change needed to further make improvements to enhance performance (Calantone et al. 2002; Chang \& $\mathrm{Ku}, 2009$ ). A learning organization pay attention to acquiring knowledge that fine-tune current knowledge and practise or look into long-held assumptions and establish new mind set (Slater \& Narver, 1995). According to the past studies, learning orientation is conceptualized as comprised of four elements: commitment to learning, open-mindedness, intra-organizational knowledge sharing and shared vision. The effective and efficient information sharing system facilitates a reevaluation of the past assessments and implementation activities (Calantone et al. 2002).

\section{Service Driven Market Orientation}

Service orientation's role is very important in the delivery of services (O'Connor, Trinh \& Shewchuk, 2000). Organizations by following the service oriented policy can deliver superior customer value and satisfy their customers in the best way. Companies through service orientation have better chances of satisfying customers by successfully implementing competitive strategy. The service-oriented companies may bring competitive advantage in the service sector by following the specific service-oriented procedures. The service firms through service 
orientation implementation have developed differentiation among competing firms (Zhang, Waszink \& Wijngaard, 2000). The service orientation concept is becoming increasingly popular because it is a fundamental cause behind creating superior customer value, customer satisfaction, growth, profit and loyalty (Eren, Eren, Ayas \& Hacioglu, 2013). Service orientation is one of the key elements of the organization characteristics that develop a service culture in which employee actions create and deliver excellent services and seen to possess helpful, kind, sincere and cooperative personality (Yoon, Choi \& Park, 2007; Eren et al. 2013). Service orientation is the component of service culture in which managers are service enthusiasts and engage in activities that show concern for organizational clients (Eren et al. 2013; Lytle \& Timmerman, 2006).

The service orientation is the set of practices, events and procedures within an organization that count on service excellence and differentiate an organization from others because of the distinguished features about service quality and service delivery that encourage positive employee behaviours that leads to provision of excellent service, distinctive practices and encourage employee behaviours (Kelley, 1992). Market orientation is essential for business management and administration and its key target is to satisfy customers because stay close to customers is important for most successful organizations (Voon, 2006). The philosophy of market orientation emphasis on placing customer in first place leads to achieving competitive advantage in the market place and produce customer value that is unique and difficult to imitate. According to Day (1999) market orientation is strategic necessity through which organizations continuously anticipate and react to the changing demands of the customers as well as market environments. Voon (2006) developed a scale measuring service-driven market orientation that is more service oriented and termed as service-driven market orientation (SERVMO), defined as "the set of beliefs, behaviours, and cross-functional processes that seriously focuses on continuous and comprehensive understanding, disseminating, as well as satisfying the current and future needs of the target customers, for service excellence" . Customer opinion is critical in quality management and it is deemed that the same way is applicable in the servicedriven market orientation. Due to this fact, customers' point of view is important and invaluable while analysing the market orientation of an organization. Deshpande', Farley \& Webster (1993), in their empirical study pointed out customer specific market orientation ought to be essential in service quality management. According to Matthing, Sande'n, \& Edvardsson (2004) service-centred view assessment of new service creation ought to be harnessed through customer engagement.

This instrument is application of market orientation philosophy in the area of service quality management. Voon (2006) includes the market orientation scales of Narver and Slater (1990) and Deshpande'and Farley (1998), extra items were included in the SERMO scale to capture the customer-perceived market orientation in the service economy. The scale of Voon (2006) comprises :

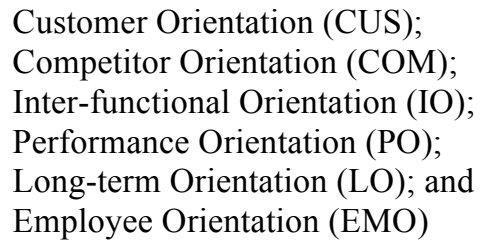

Voon (2006) emphasis that market-oriented service organization should possess and implement all the six dimensions of the SERVMO to sustain and achieve superior service quality in their target market.

\section{Leaning Orientation and Service-Driven Orientation}

A market orientation is useful because it targets the firms on continuously accumulating information and facts about target consumers' needs and wants and competitor's capabilities as well as applying this knowledge to generate continuously outstanding customer value. Many researchers like (Baker \& Sinkula, 1999; Slater \& Narver, 1995) proposed that when market-orientation and learning orientation work together, they boost firm's performance. Market-oriented firms target customers in the established markets and they overlook the emerging markets, technologies and competitors. Nevertheless, learning-orientation, undertaking dedication to learning, openmindedness, inter-organizational knowledge sharing and shared vision promotes a list of knowledge-strengthening and knowledge-questioning principles to improve the adaptive behaviours because of implementing higher-order 
learning in the market-orientation principles results in the quest for entering new markets as well as growth and creation of innovative services, products and technologies (Slater \& Narver, 1995; Farrell, 2000). Learning orientation could be evolved in the market-oriented organizations by delivering the cultural framework (Farrell, 2000; Slater \& Narver, 1995). According to Baker and Sinkula (1999) market orientation facilitate adaptive learning whereas Day (1994) put forward the proposition that market orientation is based on organizational learning due to the fact market-driven practices will only arise if the company has the capacity to "learn to learn" regarding the market. The learning capability provides the competency to learn at accelerated rate and better than rivals and leads to long lasting competitive advantage. Learning-oriented firms search for new solutions by utilizing market-based knowledge and attain and distribute information regarding markets and additionally always explore dynamics of the market (Baker \& Sinkula, 1999). Customer orientation and competitor orientation are substantially influenced by learning orientation. The level of learning orientation implementation has big influence on market orientation and business performance (Lee \& Tsai, 2005). Keskin (2006) in SMEs of developing nations, studied the relationship among learning-orientation, market-orientation and innovativeness. It was found that learning-orientation explicates marketing behaviour into successful practices to enhance innovation. The firms operationalize their marketorientation activities and get rid of inhibiting attitudes and suppositions about the current markets with learningorientation, on the ground that market-orientation in SMEs run by the feedbacks of customers, is a mechanistic and narrow kind of innovation-producing operational productivity. According to him, firms switch from adaptive learning that could be reflected in cost and operational efficiency towards a higher-order learning showing radical innovations as well as search for new markets and technology by means of learning orientation. In this way learningorientation is undoubtedly a distinguished way to improve the capacities of market-orientation for SMEs so that they deal with globalization and also the greater rate of rivalry and evolving markets and technologies. The past research reveals that learning orientation play a vital role to engage in strengthening bonds with customers (Boulding, Staelin, Ehret \& Johnston, 2005; Chang \& Ku, 2009). Boulding et al. (2005) claimed that scholars began paying more focus on figuring out the key capabilities of the firm important to build and sustain decent customer relationships.

Table 1. Outlines of Some Studies Regarding Market Orientation - Learning Orientation - Innovativeness

\begin{tabular}{|c|c|c|c|}
\hline Study & Data source & Analysis Tool/technique & Findings \\
\hline $\begin{array}{l}\text { Keskin } \\
(2006)\end{array}$ & $\begin{array}{l}157 \text { small-sized- } \\
\text { firms operating in } \\
\text { Turkey }\end{array}$ & $\begin{array}{l}\text { Structural equation } \\
\text { modelling }\end{array}$ & $\begin{array}{l}\text { - Firm innovativeness has positive influence on firm } \\
\text { performance. } \\
\text { - Firm learning-orientation has positive relationship with firm } \\
\text { innovativeness. } \\
\text { - There is significant relationship between market-orientation } \\
\text { and firm learning orientation. } \\
\text { - Between Market-orientation and innovativeness, learning } \\
\text { orientation acts as a mediator. } \\
\text { - The relationship between Firm market-orientation and } \\
\text { innovation is indirect which is influenced by learning } \\
\text { orientation. }\end{array}$ \\
\hline $\begin{array}{l}\text { Lin, Peng \& } \\
\text { Kao (2008). }\end{array}$ & $\begin{array}{l}333 \text { venture } \\
\text { companies in } \\
\text { Taiwan }\end{array}$ & $\begin{array}{l}\text { structural equation } \\
\text { modelling }\end{array}$ & $\begin{array}{l}\text { - Learning orientation acts as a mediator in the relationship } \\
\text { between market orientation and innovativeness } \\
\text { - Market orientation enhances the innovativeness via } \\
\text { organizational learning }\end{array}$ \\
\hline $\begin{array}{l}\text { Ozmen, \& } \\
\text { Deniz Eris } \\
(2012)\end{array}$ & $\begin{array}{l}102 \text { dyads in the } \\
\text { logistics sector in } \\
\text { Turkey }\end{array}$ & $\begin{array}{l}\text { Structural Equation } \\
\text { Model }\end{array}$ & $\begin{array}{l}\text { - Market orientation and learning orientation are positively } \\
\text { correlated with each other. } \\
\text { - Significant link between learning orientation and } \\
\text { Innovativeness. } \\
\text { - Significant positive relation between innovativeness and } \\
\text { performance. }\end{array}$ \\
\hline $\begin{array}{l}\text { Lee \& Tsai } \\
(2005)\end{array}$ & $\begin{array}{l}700 \text { firms in } \\
\text { Taiwan including } \\
\text { both manufacturing } \\
\text { and service firms }\end{array}$ & $\begin{array}{l}\text { Structural equation } \\
\text { modelling }\end{array}$ & $\begin{array}{l}\text { - The relationship between organizational innovation and market } \\
\text { orientation is affected by levels of implementation of learning } \\
\text { orientation. } \\
\text { - Market orientation and learning orientation have effect on } \\
\text { innovation and firm performance, but mode of business } \\
\text { operations takes on critical part relating to the degree of impact. }\end{array}$ \\
\hline
\end{tabular}


H1: The relationship between learning orientation and service-driven market orientation is significant.

\section{Learning Orientation and Service Innovation}

Innovation involves effectively employing unique ideas within an organization (Amabile, Conti, Coon, Lazenby \& Herron, 1996) and consequently strongly linked to organizational learning. Innovation on the whole is conceptualized as a learning approach that is designed to uncover new methods of managing issues. Therefore, innovation appears to be dependent on firm's ability to learn how new knowledge is created, passed out and utilized (Alegre \& Chiva, 2008). The primary principle is that companies who are in a position to learn, have far better opportunity of knowing the results of the transformations in their surroundings and are more effective than rivals to answer swifter and superior to them because they are strongly willing to improve business significant logics whenever they are put under some business challenges (Tippins \& Sohi, 2003). Organizational learning has been linked to better and new innovations, call for an improvement in the manner business were perceived ahead of time as opposed to market orientation which is linked with more reactive innovations (Baker \& Sinkula, 2002; JiménezJimenez,2008). Organizations adaption to the changing environment depends on their learning capability. Morgan and Strong (1997) suggested that learning is mainly related with steady improvement of organizational deficiencies and enhancement of knowledge ingestion in achieving competitive edge. Hurley and Hult (1998) claim that enhanced degree of innovations are connected to cultures stress on learning and growth. Learning is about discovery and innovation is about capitalizing the business opportunity.

Figure 1. Conceptual Framework

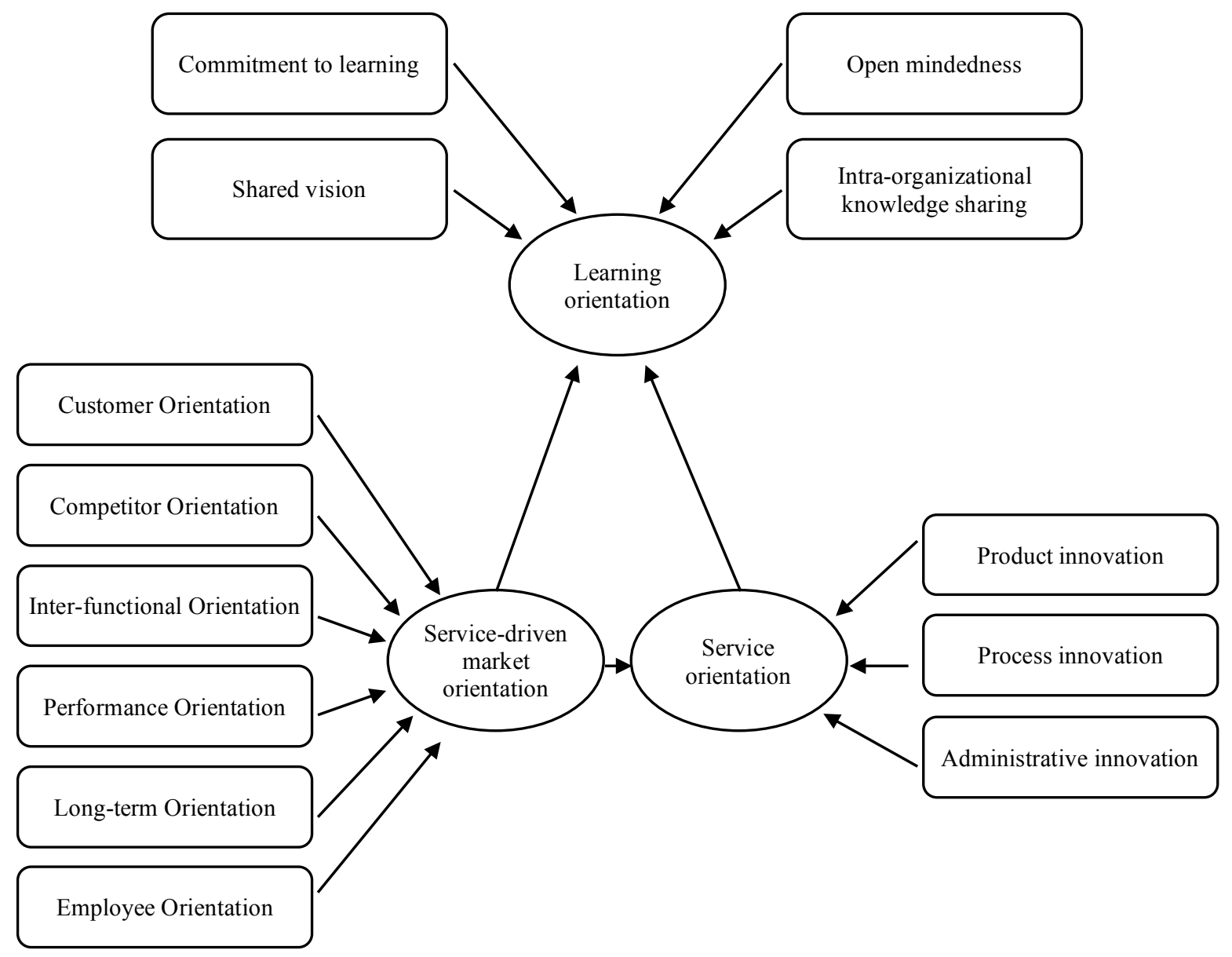


Many researchers have pointed out that learning orientation and innovations are very much linked with each other (Lin et al. 2008; Hurley, Hult \& Knight, 2003; Baker \& Sinkula, 2002; Calantone et al. 2002). Calantone et al. (2002) asserted that higher degree of learning orientation leads to better innovation. Learning orientation is considerably related to innovative ideas in organizations. Learning orientation is the foremost antecedent of innovativeness (Hurley et al. 2003).

Jiménez-Jimenez et al. (2008) in their paper investigated the impact of organizational learning capability on innovation performance. They provided the empirical evidence that organizational learning capability foster innovation (product innovation, process innovation and administrative innovation). Yli-Renko, Autio \& Sapienza (2001) concluded positive connection between knowledge acquisition and product innovation. A firms learning orientation accomplishments impacts product innovation and organizational performance by generative learning, as a consequence, resulting in innovations in products, processes and techniques (Baker \& Sinkula, 1999). The relationship between learning orientation and innovation is the fact that learning sets basis for innovation due to the fact an organization's reliance on learning improves its innovation capability, and additionally, simultaneously affecting its overall firm performance (Ozmen \& Deniz Eris, 2012). A few of the studies regarding connection between learning orientation \& innovativeness and their results produced through these researches are summarized in table 2.

Table 2. Outlines of Some Studies Regarding Learning Orientation - Innovativeness

\begin{tabular}{|c|c|c|c|}
\hline Study & Data source & $\begin{array}{c}\text { Analysis } \\
\text { Tool/technique }\end{array}$ & Findings \\
\hline $\begin{array}{c}\text { Calantone, } \\
\text { Cavusgil \& Zhao } \\
\quad(2002)\end{array}$ & 187 US industries & $\begin{array}{l}\text { Structural equation } \\
\text { model }\end{array}$ & $\begin{array}{l}\text { - Learning orientation is positively correlated } \\
\text { with firm innovativeness. } \\
\text { - Learning orientation is crucial for innovation } \\
\text { and performance. }\end{array}$ \\
\hline $\begin{array}{l}\text { Lee \& Tsai } \\
\quad(2005)\end{array}$ & $\begin{array}{l}700 \text { manufacturing } \\
\text { and service firms }\end{array}$ & $\begin{array}{l}\text { Structural equation } \\
\text { model }\end{array}$ & $\begin{array}{l}\text { There is Significant relationship between } \\
\text { Market orientation, learning orientation \& } \\
\text { organizational innovativeness. }\end{array}$ \\
\hline $\begin{array}{l}\text { Jiménez-Jimenez, } \\
\text { Valle \& Hernandez- } \\
\text { Espallardo } \\
\text { (2008) }\end{array}$ & $\begin{array}{l}744 \text { firms including } \\
\text { wide range of } \\
\text { industries }\end{array}$ & $\begin{array}{l}\text { Structural equation } \\
\text { model }\end{array}$ & $\begin{array}{l}\text { - Market orientation foster innovation. } \\
\text { - Learning orientation foster innovation, but } \\
\text { impact of learning orientation on innovation } \\
\text { greater than market orientation. }\end{array}$ \\
\hline $\begin{array}{l}\text { Alegre \& Chiva } \\
\text { (2008) }\end{array}$ & $\begin{array}{l}182 \text { firms from } \\
\text { ceramic tile industry }\end{array}$ & $\begin{array}{l}\text { Structural equations } \\
\text { modelling }\end{array}$ & $\begin{array}{l}\text { - Found positive connection between the } \\
\text { organizational learning requirement and } \\
\text { innovation. } \\
\text { - Product innovation performance is a function } \\
\text { of organizational learning capability. }\end{array}$ \\
\hline
\end{tabular}

Therefore, the following hypotheses have been formulated:

H2a: There is positive and significant relationship between Learning orientation and product innovation.

H2b: There is positive and significant relationship between Learning orientation and process innovation.

H2c: There is positive and significant relationship between Learning orientation and administrative innovation.

\section{Service-Driven Orientation and Service Innovation}

Drucker, one of the top pioneers to talk about the philosophy associated with the marketing concept in the area of business administration, foresee that firms have two fundamental functions: marketing and innovation. In this perspective, though there was this sort of early trend in the direction of talking about market orientation and innovations together (Olavarrieta \& Friedmann, 2008). Market orientation basically demands innovative behaviour in agreement with the market's environment and these two aspects are greeted together (Ozmen et al. 2012). 
Market orientation is a paradigm to produce new ideas and an urge in an effort to react to the environment and encourage innovativeness (Hurley \& Hult, 1998). Excellent quality performance depends on higher level of market orientation centred on innovation, as a consequence of regular examining of customer priorities and opponents activities, distributing that details within organization and figuring it out (Jaworski \& Kohli, 1996). This discovery coincides with Kandampully and Duddy (1999) who recommended that market oriented companies possess the potential to predict new trends.

Intelligence generation dimension of market orientation requires acquiring information and facts for present customer preferences as well as considering all the environmental factors that could possibly prototype these expectations. (Jaworski \& Kohli, 1996) pointed out that existing and future perception of the market facilitates new product development with significant amount of integrated originality. Designing of successful competitive solutions depends on Market orientation. By exploiting the already present knowledge of customers, rivals and technologies, firm yields new, well timed and innovative products/service (Deshpande et al. 1993). Therefore, innovations are productive measure of the competence of the firm to collect knowledge and exploit that information. This is generally exhibited by initiating new products/services that most appropriate fulfil or forecast customers' desires (Mavondo, Chimhanzi \& Stewart, 2005). Atuahene-Gima (1996) observed positive relationship between firm's innovation capability and market orientation. Likewise, market oriented firms are capable of delivering and accomplish exceptional organizational performance simply because they provide market new products with high success rate (Gatignon \& Xuereb, 1997).

Service driven market orientation scale of Voon (2006) emphasis on customer orientation. Panesar and Markeset (2008) revealed that market demands and customers initiatives are the foremost important service innovation process drivers, and the critical action to reinforce service innovation is customers' feedback. Moreover, service innovation (either through designing new services or enhancing the present services) is the outcome of communication and interaction with customers.

Kandampully (2002) emphasized that customer-focused organizations are in a position to develop new and superior ways to serve their consumers. The results revealed that technology, knowledge and networks represent a vital group of parameters which stimulate innovation in service firms, because the bundled impact of technology, knowledge and networks provides the organization the power to focus its resources for the future. The most significant factor is that service innovation benefits only when firm is competent to emphasis on all its resource to think in behalf of their consumers.

Finally, service innovation process is complex as it relies upon management and coordination for huge number of inter-organizational tasks and relationships between different managerial levels, in addition to service innovation process is based on thoughtful planning and comprehensive understanding of customers' needs, wants and priorities (Panesar \& Markeset, 2008). 
Table 3. Outlines of Some Studies Regarding Market Orientation - Innovativeness

\begin{tabular}{|c|c|c|c|}
\hline Study & Data source & $\begin{array}{c}\text { Analysis } \\
\text { Tool/technique }\end{array}$ & Findings \\
\hline $\begin{array}{l}\text { Agarwal, Erramilli } \\
\text { \& Dev (2003) }\end{array}$ & $\begin{array}{l}\text { Data from } 201 \\
\text { international hotels }\end{array}$ & $\begin{array}{l}\text { Regression } \\
\text { analysis }\end{array}$ & $\begin{array}{l}\text { - Market innovation spurs service innovation. } \\
\text { - Service innovation improves judgmental } \\
\text { performance. } \\
\text { - Judgmental performance enhances objective } \\
\text { performance. }\end{array}$ \\
\hline $\begin{array}{l}\text { Vázquez Santos \& } \\
\text { Álvarez (2001) }\end{array}$ & $\begin{array}{l}264 \text { companies from } \\
\text { different sectors }\end{array}$ & Regression analysis & $\begin{array}{l}\text { - Market-oriented firms have more innovations } \\
\text { than their competitors. } \\
\text { - Market orientation affects the company's rate of } \\
\text { innovation and new product development. }\end{array}$ \\
\hline Huhtala (2011) & $\begin{array}{l}269 \text { include companies } \\
\text { from all industries }\end{array}$ & $\begin{array}{l}\text { Structural equation } \\
\text { modelling }\end{array}$ & $\begin{array}{l}\text { - When economy is booming, customer orientation } \\
\text { and inter-functional coordination have significant } \\
\text { influence, while during downturn, competitor } \\
\text { orientation plays a stronger role in in building } \\
\text { innovation capability. }\end{array}$ \\
\hline $\begin{array}{l}\text { Erdil, Erdil } \\
\text { \& Keskin (2004) }\end{array}$ & $\begin{array}{l}120 \text { industrial firms in } \\
\text { the Marmara Region }\end{array}$ & $\begin{array}{l}\text { Factor analysis \& } \\
\text { Correlational analysis }\end{array}$ & $\begin{array}{l}\text { - Market-oriented strategies enhance firms' } \\
\text { innovative capacity and performance. }\end{array}$ \\
\hline
\end{tabular}

Therefore, the following hypotheses have been formulated:

H3a: There is positive and significant relationship between service-driven market orientation and product innovation.

H3b: There is positive and significant relationship between service-driven market orientation and process innovation.

H3c: There is positive and significant relationship between service-driven market orientation and administrative innovation.

\section{CONCLUSION}

The objective of this paper was to review the current literature regarding the relationship between service-driven market orientation and innovation in services firms and to formulate a research framework. Authors suggest that relationship between service-driven market orientation and service innovation is more powerful than the marketorientation and service innovation. The future empirical studies should attain comparative results via the usage of SERMO scale to study the influence of service driven market orientation on service innovation.

According to Voon (2006) the component customer orientation of SERMO scales emphasis on knowledge of the target customers and quick respond to their needs and wants so as to generate continuous and excellent customer value in the service. Customer orientation is vital for attaining superior service quality and there is substantially positive and significant link between incremental innovation and customer orientation which, subsequently brings out new service innovation. Customer orientation is apparently the chief factor for accomplishing incremental innovation in the service firms. Innovative pursuits in market orientation could be the critical factor when customers' choices and business structures are shifting fast. This is due to the fact this sort of factors can enforce service firms to innovate more quickly and frequently even in the stable markets. Customer orientation ought to be perceived as the beginning point in launching incremental service innovation (Cheng \& Krumwiede, 2012). The inter-functional orientation is important component of SERMO. The inter-functional coordination leads to new product development due to its focus on sharing of market information (Im \& Workman 2004). It is usually suggested to have a positive influence on innovation outcomes mainly because it creates an opportunity for distribution of creative market information that is helpful in solving the problems (Gatignon \& Xuereb, 1997). Auh and Menguc (2005) suggested that it could support the creation, gathering and distribution of market intelligence associated with new service development spanning across different working areas. Furthermore, it relates to idea 
sharing, problem solving, and pioneering receptiveness (Han, Kim \& Srivastava, 1998). Therefore, for this reason, it is usually linked with positive influence on radical innovation simply because it enables distribution of creative knowledge about market and promotes problem solving. However, considering service environment, inter-functional coordination could be found within the sharing of market knowledge that could be critical for the development of new service (Im \& Workman, 2004; Henard \& Szymanski, 2001). Incremental service orientation is influenced by the customer orientation whereas radical service innovation is positively associated with inter-functional coordination, each of which subsequently leads to new service success (Cheng \& Krumwiede, 2012).

The market-oriented firm is believed to possess superior market-sensing customer-linking proficiency; it needs to be capable of "innovate" in such a way that delivers outstanding value for their targeted customers. Service firms could possibly achieve this by creating new products/services, building new distribution channels or competitive strategy or discovering new processes for management (Slater \& Narver, 1995).

The SERMO instrument can be successfully employed by the managers to assess and monitor the extent of SERMO implementation in their specific organizations. The scores for different SERMO factors can provide the important insight relating to the diverse market oriented service practices that has to improve in an effort to boost service performance. As a managerial tool, SERVMO can assist managers to comprehend, evaluate and strengthen the understanding of service management practices and performance (Voon, 2006). Authors suggest that organizations which are service-driven market oriented firms can accomplish winning edge in service delivery since they are capable of figuring out their customers' current and future needs as well as provide a plan for services that may particularly satisfy their respective needs and wants. Many service-oriented firms are aiming to assimilate novel traits into their services to increase customer satisfaction and loyalty. Service-driven market-oriented firms assumed to have the ease of knowing their customers much better than their competitors. The rendering of service-driven market orientation could empower managers to discover more innovative services which are economically useful for firms as well as needed by the customers. It might direct firms' competence to distinguish itself from its competitors and contribute much more to a firm's revenues. The service-driven market orientation is capable of focus all its potential to think behalf of their customers and could result in more innovative services.

\section{AUTHOR BIORAGPHIES}

Seng Ratny is a Ph.D. Student in the School of Management, at Xi'an Jiaotong University, in Shaanxi, P. R. China. E-mail: ratnys@yahoo.com; sengratny@stu.edu.cn (corresponding author).

Arif Mohammad Arshad is a Ph.D. Candidate in the School of Management, at Xi'an Jiaotong University in Shaanxi, P. R. China. E-mail: marshadarif@yahoo.com.

Gao-Liang Tian is a Professor in the School of Management at Xi'an Jiaotong University in Shaanxi, P. R. China. E-mail: tian.gl@mail.xjtu.edu.cn.

\section{REFERENCES}

Agarwal, S., Erramilli, M. K., \& Dev, C. S. (2003). Market orientation and performance in service firms: Role of innovation. Journal of Services Marketing, 17(1), 68-82.

Alam, I. \& Perry, C. (2002): A customer-oriented new service development process. Journal of Services Marketing, 16(2), $515-$ 534.

Alegre, J., \& Chiva, R. (2008). Assessing the impact of organizational learning capability on product innovation performance: An empirical test. Technovation, 28(6), 315-326.

Amabile, T. M., Conti, R., Coon, H., Lazenby, J., \& Herron, M. (1996). Assessing the work environment for creativity. Academy of Management Journal, 39(5), 1154-1184.

American Heritage Dictionary of the English Language (2000), Houghton Mifflin, Boston, MA, available at: www.dictionary.com (accessed 14th August, 2014)

Atuahene-Gima, J. (1996). Market orientation and innovation. Journal of Business Research, 35(2), 93-103.

Auh, S., \& Menguc, B. (2005). Top management team diversity and innovativeness: The moderating role of interfunctional coordination. Industrial Marketing Management, 34(3), 249-261. 
Axtell, C.M., Holman, D.J., Unsworth, K.L., Wall, T.D., Waterson, P.E. \& Harrington, E. (2000). Shopfloor innovation: Facilitating the suggestion and implementation of ideas. Journal of Occupational and Organizational Psychology, 73, 265-85

Baker, W.E. \& Sinkula, J.M. (1999). The synergistic effect of market orientation on organizational performance. Journal of the Academy of Marketing Science, 27,411-27.

Baker, W.E. \& Sinkula, J.M. (2002). Market orientation, learning orientation and product innovation: Delving into the organization's black box. Journal of Market-focused Management, 5(1), 5-23

Battor, M., \& Battour, M. (2013). Can organizational learning foster customer relationships? Implications for performance. The Learning Organization, 20(4/5), 279-290.

Berry, L. L., Shankar, V., Parish, J. T., Cadwallader, S. \& Dotzel, T. (2006). Creating new markets through service innovation. Sloan Management Review, 47(2), 56-63

Boulding, W., Staelin, R., Ehret, M. \& Johnston, W. (2005). A customer relationship management roadmap: What is known, potential pitfalls, and where to go. Journal of Marketing, 69(4), 155-166

Boyd, H. \& Walker, O. (1990). Marketing management: A strategic approach. Richard Irwin Inc., Chicago, IL.

Calantone, R., Cavusgil, S.T. \& Zhao, Y. (2002). Learning orientation, firm innovation capability, and firm performance. Industrial Marketing Management, 31(6), 515-524

Celuch, K., Kasouf, C. \& Pemvemb, V. (2002). The effects of perceived market and learning orientation on assessed organizational capabilities. Industrial Marketing Management, 31(6), 545-554

Chang, H.H. \& Ku, P.W. (2009). Implementation of relationship quality for CRM performance: Acquisition of BPR and organisational learning. Total Quality Management, 20(3), 327-348

Cheng, C. C., \& Krumwiede, D. (2012). The role of service innovation in the market orientation-new service performance linkage. Technovation, 32(7), 487-497.

Cohen, W.M. \& Levinthal, D.A. (1990). Absorptive capacity: A new perspective on learning and innovation. Administrative Science Quarterly, 35, 128-52.

Damanpour, F. (1991). Organizational innovation: a meta-analysis of effects of determinants and moderators. Academy of Management Journal, 34(3), 550-90.

Damanpour, F., Szabat, K. A., \& Evan, W. M. (1989). The relationship between types of innovation and organizational performance. Journal of Management studies, 26(6), 587-602.

Day, G. S. (1994). The capabilities of market-driven organizations. the Journal of Marketing, 37-52.

Day, G. S. (1999). Creating a market-driven organization. MIT Sloan Management Review, 41(1), 11.

Deshpandé, R., \& Farley, J. U. (1998). Measuring market orientation: Generalization and synthesis. Journal of Market-Focused Management, 2(3), 213-232.

Deshpande', R., Farley, J.U. \& Webster, F.E. (1993). Corporate culture, customer orientation, and innovativeness in Japanese firms: A quadrad analysis. Journal of Marketing, 57(1), 23-37

Drucker, P.F. (1985). The discipline of innovation. Harvard Business Review, 63(3), 67-72.

Erdil, S., Erdil, O., \& Keskin, H. (2004). The relationships between market orientation, firm innovativeness and innovation performance. Journal of Global Business and Technology, 1(1), 1-11.

Eren, S. S., Eren, M. Ş., Ayas, N., \& Hacioglu, G. (2013). The effect of service orientation on financial performance: The mediating role of job satisfaction and customer satisfaction. Procedia-Social and Behavioral Sciences, 99, 665-672

Fang, S. R., Chang, E., Ou, C. C., \& Chou, C. H. (2014). Internal market orientation, market capabilities and learning orientation. European Journal of Marketing, 48(1/2), 170-192.

Farrell, M. (2000). Developing a market-oriented learning organization. Australian Journal of Management, 25, 201-22.

Frimpong, K., \& Wilson, A. (2012). Measuring service orientation of service delivery employees. La Londe les Maures.

Gadrey, J., Gallouj, F. \& Weinstein, O. (1995). New modes of innovation: How services benefit industry. International Journal of Service Industry Management, 6(3), 4-16.

Garg, R. K. \& Chan. K. K, (1997). Service orientation and small business marketing. Journal Professional Services Marketing, $15(2), 131-143$

Gatignon, H., \& Xuereb, J. M. (1997). Strategic orientation of the firm and new product performance. Journal of Marketing Research, 77-90.

Han, J. K., Kim, N., \& Srivastava, R. K. (1998). Market orientation and organizational performance: Is innovation a missing link?. The Journal of Marketing, 30-45.

Harrison, R. T. \& Leitch, C. M. (2005). Entrepreneurial learning: Researching the interface between learning and the entrepreneurial context. Entrepreneurship Theory and Practice, 29(4), 351-371.

Henard, D. H., \& Szymanski, D. M. (2001). Why some new products are more successful than others. Journal of Marketing Research, 38(3), 362-375.

Huhtala, J. P. (2011). Market orientation, innovation capability and business performance: Insights from different phases of the business cycle.

Hult, G. T., Ketchen, D. \& Slater, S. (2002). A longitudinal study of the learning climate and cycle time in supply chains. Journal of Business \& Industrial Marketing, 17(4), 302-323 
Hurley, R.F. \& Hult, G.T. (1998). Innovation, market orientation and organisational learning: An integration and empirical examination. Journal of Marketing, 62(3), 42-54.

Hurley, R. F., Hult, G. T. M. \& Knight, G. A. (2003). Innovativeness: Its antecedents and impact on business performance. Industrial Marketing Management, 33, 429-38.

Im, S., \& Workman, J. (2004). Market orientation, creativity, and new product performance in high-technology firms. Journal of Marketing, 68,114-132.

Jaworski, B.J. \& Kohli, A.K. (1996). Market orientation: Review, refinement, and roadmap. Journal of Market Focused Management, 1, 119-35.

Jiménez-Jimenez, D., Valle, R. S., \& Hernandez-Espallardo, M. (2008). Fostering innovation: The role of market orientation and organizational learning. European Journal of Innovation Management, 11(3), 389-412.

Johne, A. \& Storey, C. (1998). New service development: A review of the literature and annotated bibliography. European Journal of Marketing, 32(3/4), 184-251

Kandampully, J. \& Duddy,R.(1999). Competitive advantage through anticipation, innovation and relationships. Management Decision, 37(1), 6-51.

Kandampully, J. (2002).Innovation as the core competency of a service organization: the role of technology, knowledge and networks. European Journal of Innovation Management, 5(1), 18-26.

Kelley, S. W. (1992). Developing customer orientation among service employees. Journal of the academy of Marketing Science, 20(1), 27-36.Keskin, H. (2006). Market orientation, learning orientation, and innovation capabilities in SMEs: An extended model. European Journal of Innovation Management, 9(4), 396-417.

Kim, N. \& Atuahene-Gima, K. (2010). Using exploratory and exploitative market learning for new product development. Journal of Product Innovation Management, 27, 519-536.

Kohli,A. \& Jaworki, B.J. (1990). Market orientation: The construct, research propositions, and managerial implications. Journal of Marketing, 54, 1-18

Krepapa, A., Berthon, P., Webb, D. \& Pitt, L. (2003). Mind the gap: an analysis of service provider versus customer perceptions of market orientation and the impact on satisfaction. European Journal of Marketing, 37(1/2), 197-218.

Lee, T. S., \& Tsai, H. J. (2005). The effects of business operation mode on market orientation, learning orientation and innovativeness. Industrial Management \& Data Systems, 105(3), 325-348.

Levitt, T. (1960). Marketing Myopia, Harvard Business Review, July-August, 1960. LevittJuly45Harvard Business Review1960, 45-56.

Lin, C. H., Peng, C. H., \& Kao, D. T. (2008). The innovativeness effect of market orientation and learning orientation on business performance. International Journal of Manpower, 29(8), 752-772.

Lytle, R.S. \& Timmerman J. E. (2006). Service orientation and performance: an organizational perspective. Journal of Services Marketing, 20(2), 136-147

Matear, S., Osborne, P., Garrett, T. \& Gray, B. (2002). How does market orientation contribute to service firm performance? European Journal of Marketing, 36(9/10), 1058-1075

Matthews, J. \& Shulman, A. D. (2005). Competitive advantage in public-sector organizations: Explaining the public good/sustainable competitive advantage paradox. Journal of Business Research, 58, 232-40.

Matthing, J., Sande'n, B. \& Edvardsson, B. (2004). New service development: Learning from and with customer. International Journal of Service Industry Management, 15(5), 479-98

Mavondo, F. T., Chimhanzi, J., \& Stewart, J. (2005). Learning orientation and market orientation: relationship with innovation, human resource practices and performance. European Journal of Marketing, 39(11/12), 1235-1263.

Menor, L. J., Tatikonda, M. V., \& Sampson, S. E. (2002). New service development: Areas for exploitation and exploration. Journal of Operations Management, 20(2), 135-157

Morgan, R.E. \& Strong, C. (1997). Market orientation and dimensions of strategic orientation. European Journal of Marketing, 32(11/12), 1051-73.

Narver, J. C., \& Slater, S. F. (1990). The effect of a market orientation on business profitability. The Journal of Marketing, 20-35.

O'Connor, S. J., Trinh, H. Q., \& Shewchuk, R. M. (2000). Determinants of service orientation among medical students. Advances in Health Care Management, 1(0), 217-249.

Oke, A. (2007). Innovation types and innovation management practices in service companies. International Journal of Operations \& Production Management, 27(6), 564-587.

Olavarrieta, S., \& Friedmann, R. (2008). Market orientation, knowledge-related resources and firm performance. Journal of business research, 61(6), 623-630.

Osborne, S. (1998). Voluntary organizations and innovation in public services. London: Routledge

Ozmen, O. N. T., \& Eris, E. D. (2012). The effect of market orientation, learning orientation and innovativeness on firm performance: A research from Turkish logistics sector. International Journal of Economic Sciences and Applied Research, (1), 77-108.

Panesar,S. S. \& Markeset, T. (2008). Developing of a framework for industrial service innovation management and coordination. Journal of Quality in Maintenance Engineering, 14(2), 177-193.

Parasuraman, A., Berry, L. L., \& Zeithaml, V. A. (1983). Service firms need marketing skills. Business horizons, 26(6), $28-31$. 
Peters, T. \& Waterman, R. (1982). In search of excellence: Lessons from America's best-run companies. Warner Books Inc., New York, NY Pilat, D., 2000. No longer services as usual. The OECD Observer, 223, 52-54.

Pilat, D. (2000). No longer services as usual. Organisation for Economic Cooperation and Development. The OECD Observer, (223), 52.

Rönnbäck, Å., \& Witell, L. (2008). A review of empirical investigations comparing quality initiatives in manufacturing and service organizations. Managing Service Quality: An International Journal, 18(6), 577-593.

Saxe, R., \& Weitz, B. A. (1982). The SOCO scale: A measure of the customer orientation of salespeople. Journal of Marketing Research, 343-351.

Sinkula, J., Baker, W. \& Noordewier, T. (1997). A framework for market-based organizational learning: Linking values, knowledge, and behavior. Journal of the Academy of Marketing Science, 25(4), 305-318

Slater, S. F., \& Narver, J. C. (1995). Market orientation and the learning organization. The Journal of Marketing, 63-74.

Storey, C., Easingwood, C.J., 1999. Types of new product performance: Evidence from the consumer financial sector. Journal of Business Research, 46, 193-203.

Taddese, F., \& Osada, H. (2010). Process techno-innovation using TQM in developing countries empirical study of deming prize winners. Journal of Technology Management \& Innovation, 5(2), 47-65.

Tippins, M.J. \& Sohi, R.S. (2003). IT competency and firm performance: is organizational learning a missing link. Strategic Management Journal, 24(8), 745-61.

Varis, M., \& Littunen, H. (2010). Types of innovation, sources of information and performance in entrepreneurial SMEs. European Journal of Innovation Management, 13(2), 128-154.

Vázquez, R., Santos, M. L., \& Álvarez, L. I. (2001). Market orientation, innovation and competitive strategies in industrial firms. Journal of Strategic Marketing, 9(1), 69-90.

Voon, B. H. (2006). Linking a service-driven market orientation to service quality. Managing Service Quality, 16(6), 595-619.

Yli-Renko, H., Autio, E., \& Sapienza, H. J. (2001). Social capital, knowledge acquisition, and knowledge exploitation in young technology-based firms. Strategic Management Journal, 22(6-7), 587-613.

Yoon, S. J., Choi, D.C. \& Park, J.W. (2007). Service orientation: Its impact on business performance in the medical service industry. The Service Industries Journal, 27(4), 371-380.

Zehir, C., Ertosun, Ö. G., Zehir, S., \& Müceldilli, B. (2012). Total quality management practices' effects on quality performance and innovative performance. Procedia-Social and Behavioral Sciences, 41, 273-280.

Zeithaml, V. A. (1981). How consumer evaluation processes differ between goods and services. in James H. Donelly and William R. George, (eds.). Marketing of Services, Chicago: American Marketing Association, 186-15

Zhang, Z., Waszink, A. \& Wijngaard, J. (2000). An instrument for measuring TQM implementation for Chinese manufacturing companies. International Journal of Quality \& Reliability Management, 17(7), 730-55. 
NOTES 